\title{
Study of Metal Sorption/Desorption Processes on Competing Sediment Components with a Multichamber Device
}

\author{
WOLFGANG CALMANO, WOLFGANG AHLF, and \\ ULRICH FÖRSTNER \\ University of Technology Hamburg-Harburg \\ Eissendorferstrasse 38 \\ D-2100 Hamburg 90, West Germany
}

ABSTRACT / A new multichamber device was developed to study sorption/desorption reactions of metals on different competing sediment components and the influence of environmental factors on these reactions. The system consists of a central chamber connected with six external chambers and separated by 0.45 - $\mu$ m-diameter membranes.

The diffusion kinetics of metals between the single chambers were determined. Equilibrium was attained within $24 \mathrm{~h}$. Algal cell walls (Scenedesmus quadricauda), bentonite, aluminium oxide, manganese oxide, quartz powder, and goethite were used as model sediment components. Determination of metal sorption on the solid phases resulted in a significant enrichment on the algal cell walls, particularly for $\mathrm{Cu}$ and $\mathrm{Cd}$. It was concluded that sorption depends not only on ion exchange but also on complexing reactions which lead to relatively stable surface binding. A second series of experiments investigated the effect of seawater on sediment components and dredged mud. Cadmium was remobilized from all solid components, but Cu was not remobilized from algal cell walls and bentonite.

The dominant role of organic substrates in the binding of metais such as $\mathrm{Cd}$ and $\mathrm{Cu}$ is of particular relevance for the transfer of these elements into biological systems. Even relatively small percentages of organic substrates, if involved in metabolic processes, may constitute a major pathway by which metals are transferred within the food chain.

\section{Introduction}

Increasing problems with contaminated sediments led to the question of how sediment composition is related to water quality and how its impact on aquatic ecosystems can be predicted. Several approaches to establish sediment quality are available (Battelle 1985), including sediment enrichment factors, pore water composition, and equilibrium considerations. In an activity-based model for metals, it has been suggested by Jenne and others (1986) that for an initial estimation only the quantity of "sorbed" elements must be determined. In practice, however, this approach involves certain difficulties, particularly with respect to the quantitative analysis of typical substrates over a wide spectrum of sedimentary components and also in allocating metal concentrations to these materials. Chemical extractions could give some indications on the major groups of substrate/metal associations (Forstner 1985).

These associations are the product of interactive processes which have been affected not only by the physica-chemical form of the input metals and the condition of the aqueous phase, but also by the composition and concentration of the particulate matter. Heavy metals can be sorbed by various sediment fractions like clays, detrital organic matter, iron and manganese oxides, carbonates, sulfides, bacteria and algae or other living cells. The aspect of solid concentration deserves particular attention, since experimental observations of the sorption/complexation characteristics of metals with both humic-type substances (Gamble and others 1980) and hydrous metal oxides (Benjamin and Leckie 1981, Leckie 1986), have revealed variations in binding intensity as a function of the degree of site occupancy.

Luoma and Davies (1983) suggest the following must be considered when modeling the partitioning of metals between dissolved and particulate phases in a natural system, e.g., for estuarine sediments:

- Determination of the binding intensity and capacity for important sediment components.

- Determination of the relative abundance of these components.

- Assessment of the effect of particle coatings and of multicomponent aggregation on available binding capacity of each substrate.

- Consideration of the effect of major competitors, e.g., $\mathrm{Ca}^{2+}, \mathrm{Mg}^{2+}, \mathrm{Na}^{+}, \mathrm{Cl}^{-}$.

- Evaluation of the kinetics of metal redistribution among sediment components.

Most laboratory experiments are performed with single sediment components like iron, manganese, and aluminium oxides or $\mathrm{SiO}_{2}$. Honeyman (1984) has extended these single component studies in a study of 


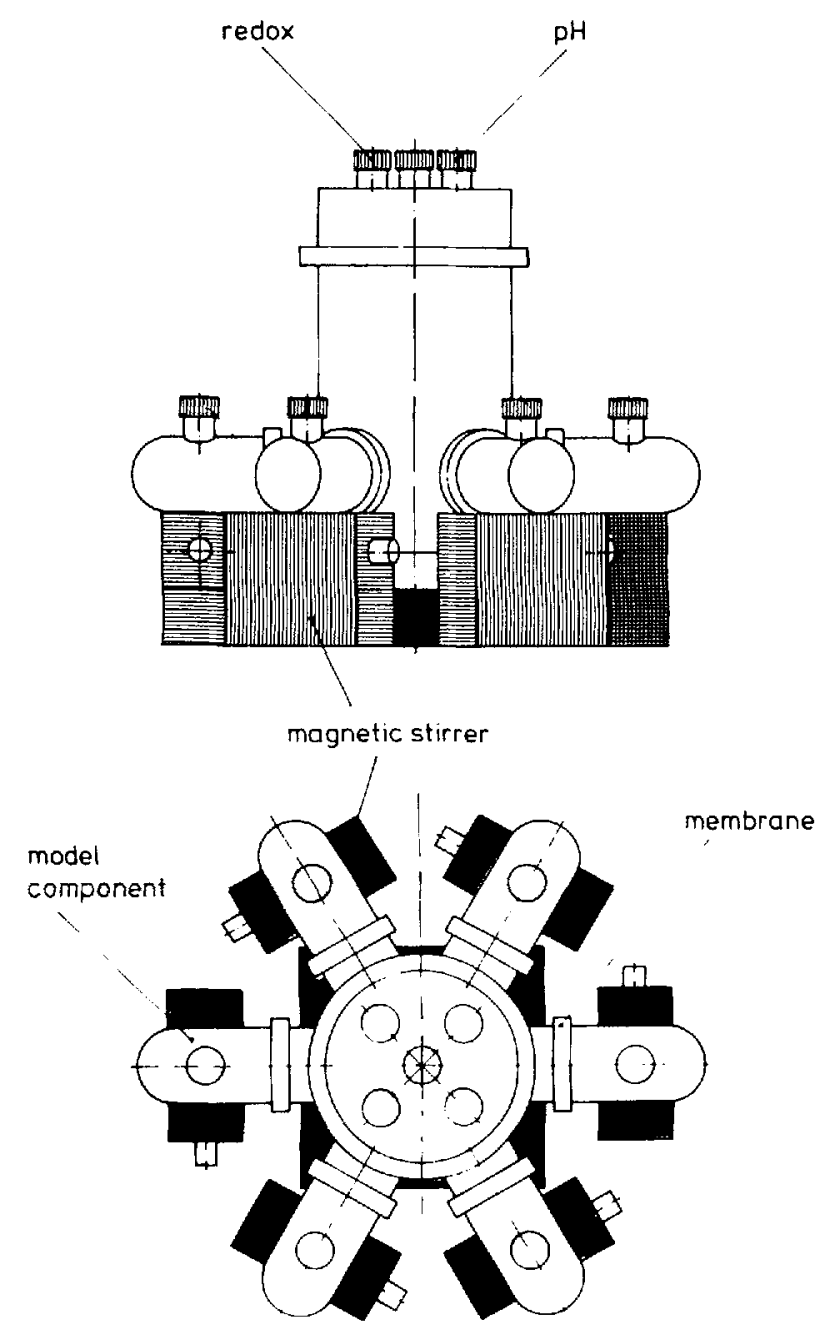

Figure 1. Schematic view of the multichamber device.

metal binding by well-defined combinations of metal oxides and a clay. He showed that adsorption characteristics are related not only to the system conditions (i.e., solid types, concentrations, and adsorbing species), but also to changes in the net system surface properties resulting from particle to particle interaction such as coagulation. Interestingly, it was found that the sorption constants for Cd, determined by using a single solid-phase systems, were applicable to solid/water systems containing two solids.

An interactive model for solid phases, in analogy to speciation in solution among soluble ligands, was developed by Davies-Colley and others (1984) from the conditional metal binding constants for a small number of sedimentary phases, the binding constants determined on individual solid phases. This model, which has been applied to the distribution of copper and cadmium in estuarine sediments, predicted that iron oxides and organic matter are the sedimentary constituents of greatest importance for these metals. A major prerequisite in use of this model is that a linear solid/solution distribution prevails for all contributing adsorbents in the sediment.

On the whole, however, the influence of particle coatings and multicomponent aggregation, major competitors (Luoma and Davis 1983), and in particular, organic ligands in the aqueous phase can rarely be predicted from such models. In addition, effects of competition between various sorption sites and the reaction kinetics of the individual constituents cannot be evaluated in a mixture of sedimentary components.

In the experimental study of these factors, as well as for predicting predominant source constituents, fluxes or mobilities, transfer mechanisms, and potential sinks of toxic metals in different sedimentary systems, it seems sensible that the individual components be separated by membranes, but in a way which still permits phase interactions via solute transport of the elements. In this way, exchange reactions, sorption/desorption processes, and biological uptake can be studied for individual phases under the influence of $\mathrm{pH}$, redox potential, ionic strength, solid and solute concentration, and other parameters. The present article describes an apparatus that permits the simultaneous study of six major sedimentary constituents and gives initial data on the effect of seawater on the interactions between these components. Such information is needed in practice to predict the possible implications of dredging processes in estuaries, and of dumping dredged material in coastal waters.

\section{Methods and Materials}

The laboratory system used in these studies was developed from our experience on sediment/algae interactions using a modified two-chambered device (Ahlf 1985, Ahlf and others 1986) originally described by DePinto (1982). The two vessels were separated by a membrane that permits diffusion of dissolved trace metals from one side to the other but prevents mixing of the solids. Figure 1 gives a schematic view of the multichamber device.

The system is made of a central chamber connected with six external chambers and separated by membranes of $0.45 \mu \mathrm{m}$ pore diameter. The use of other membranes is, of course, possible. The single solid components in each chamber are kept in suspension by magnetic stirring. Redox, $\mathrm{pH}$, and other parameters may be controlled and adjusted in each chamber.

\section{Experiments and Results}

\section{Exchange and Transfer Kinetics}

In a first experiment the diffusion kinetics of $\mathrm{Cd}$, $\mathrm{Cu}, \mathrm{Mn}, \mathrm{Ni}$, and $\mathrm{Zn}$ and the sorption of these metals 
on model sediment components were determined. The device was filled with distilled water and then certain amounts of algal cells (Scenedesmus quadricauda), bentonite, aluminium oxide (neutral, 400 mesh ASTM), goethite (synthetically made using method of Alkinson and others (1967)), and quartz powder were added to the external chambers; the sixth chamber served as control. The concentration of each solid phase was chosen so that previously determined cation exchange capacities were uniform for all components.

The following quantities were used: $0.2 \mathrm{~g}$ algal cell walls, $0.15 \mathrm{~g}$ bentonite, $1.2 \mathrm{~g} \mathrm{Al}$ oxide, $0.67 \mathrm{~g}$ goethite, and $28 \mathrm{~g}$ quartz powder. These quantities were each equivalent to a total cation exchange capacity of 90 $\mu \mathrm{M}$. After the $\mathrm{pH}$ remained constant $(\mathrm{pH}=6.5)$, metal ions were added to the central chamber.

Figure 2 shows the diffusion of $\mathrm{Cd}$ and $\mathrm{Cu}$ from the central to the external chambers through the membranes. Within $24 \mathrm{~h}$ an equilibrium was attained. While Cd concentration in solution remained constant after $3 \mathrm{~d}$, dissolved Cu decreased due to hydrolytic adsorption and precipitation with time.

Figures $3 \mathrm{~A}, \mathrm{~B}$, and $\mathrm{C}$ show the sorption of $\mathrm{Cd}, \mathrm{Cu}$, and $\mathrm{Ni}$ on the above-mentioned sediment components. A strong affinity of $\mathrm{Cd}$ to algal cell walls was found. The sorption behavior on bentonite, Al oxide, and goethite was uniform and on quartz negligible, as expected. For $\mathrm{Cu}$ uptake, algal cells were the most important sorbents, but Al oxide and goethite also showed significant sorption. This may be due to the formation of similar surface compounds for the hydrolyzed copper ions. Bentonite and quartz played a minor role in Cu uptake. Large differences in sorption of $\mathrm{Ni}$ were not observed except with quartz. These results are in accordance with the uniform cation exchange capacities of the single solids in the experiment; on the other hand, it is clear that sorption depends not only on ion exchange but also on surface complexing reactions which lead to more stable, especially "inner sphere" metal/surface and ligand/surface compounds (Leckie 1986).

\section{Sorption/Desorption in Seawater}

In a second series of experiments the ionic strength of the medium was changed and the influence of seawater on the sorption/desorption reactions of the metals studied. The quantities of the model components used were chosen to simulate an average sediment composition: $0.5 \mathrm{~g}$ algal cell walls $(=5$ percent), $3 \mathrm{~g}$ bentonite ( $=30$ percent), $1 \mathrm{~g} \mathrm{Al}$ oxide (= 10 percent), $0.5 \mathrm{~g}$ geothite ( $=5$ percent), and $5 \mathrm{~g}$ quartz powder ( $=50$ percent). Metal ions were added to the central chamber after $6 \mathrm{~d}$, when the $\mathrm{pH}$ was constant ( $\mathrm{pH}=7$ ), and the device operated for an additional

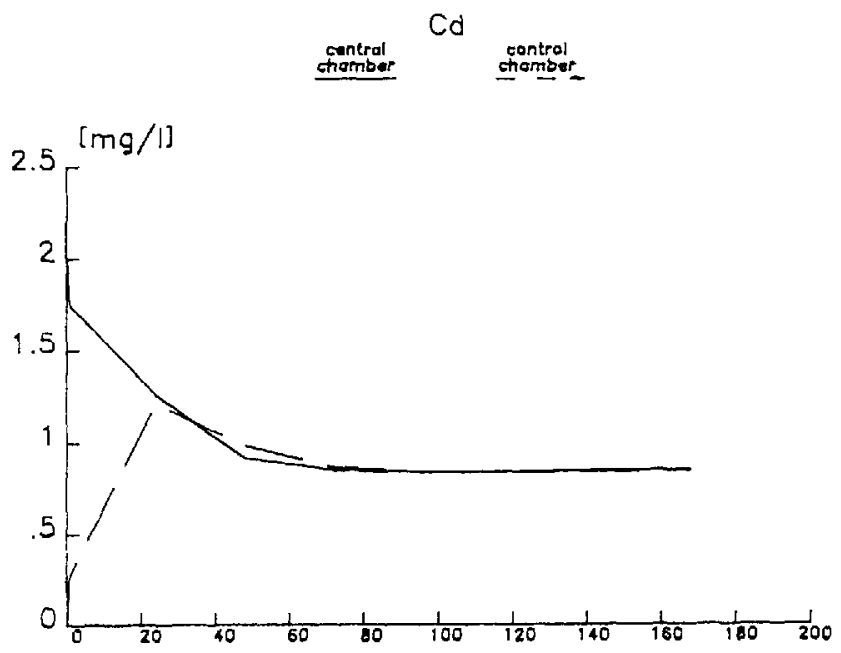

$\mathrm{Cu}$

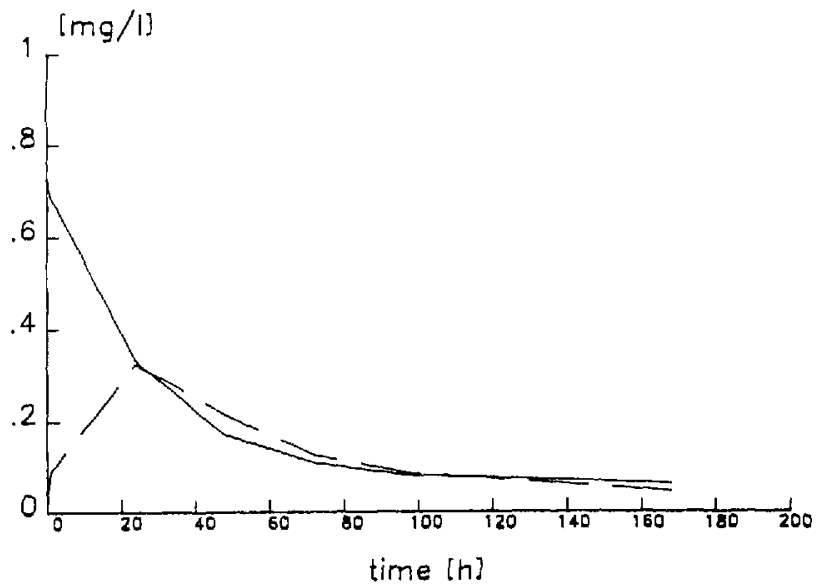

Figure 2. Exchange kinetics of $\mathrm{Cd}$ and $\mathrm{Cu}$ between central and external chambers.

$5 \mathrm{~d}$ to allow equilibration to occur. Then salts were added which provided a final concentration equivalent to that of seawater. The composition of the artificial seawater is given below $(\mathrm{g} / 1)$ :

$\begin{array}{lrllll}\mathrm{NaCl} & 21 & \mathrm{CaCl}_{2} \cdot 2 \mathrm{H}_{2} \mathrm{O}: & 1.0 & \mathrm{KBr} & : 0.1 \\ \mathrm{MgSO}_{4} \cdot 7 \mathrm{H}_{2} \mathrm{O}: & 6 & \mathrm{KCl} & : 0.8 & \mathrm{H}_{3} \mathrm{BO}_{3}: 0.06 \\ \mathrm{MgCl}_{2} \cdot 6 \mathrm{H}_{2} \mathrm{O}: & 5 & \mathrm{NaHCO}_{3} & : 0.2 & \mathrm{Sr}\left(\mathrm{NO}_{3}\right)_{2}: 0.03\end{array}$

After these additions, the $\mathrm{pH}$ increased to about 8.1 (Fig. 4).

The sorption/desorption effects for $\mathrm{Cd}, \mathrm{Zn}$, and $\mathrm{Cu}$ before and after addition of seawater salts are shown in Figures $5 \mathrm{~A}-\mathrm{C}$. The sorption was different from that observed in the previous experiment in which uniform cation exchange capacities were used, but again $\mathrm{Cd}$ showed the greatest affinity for algal cell 
A Cd uptake by different solids (amount in solution: $50 \mu \mathrm{Mol}$ )

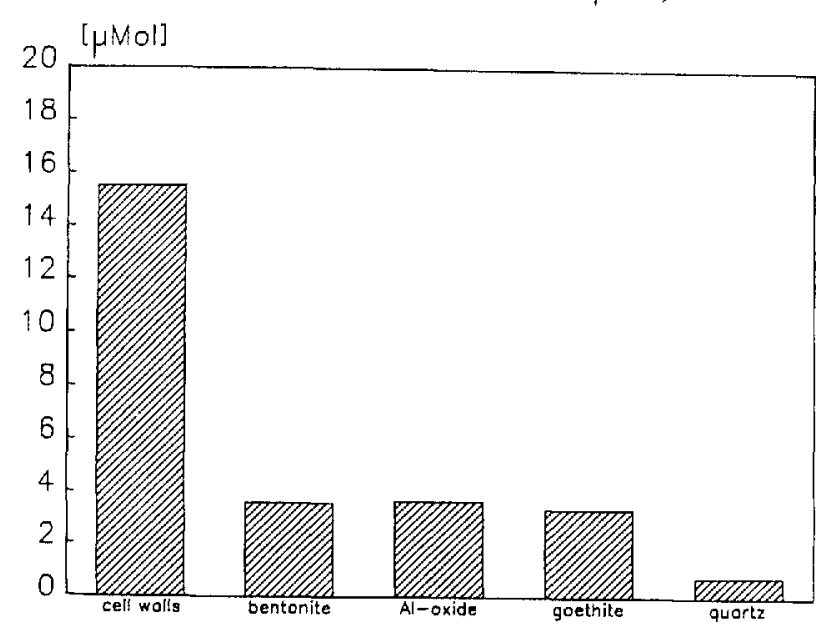

\section{C}

Ni uptake by different solids (amount in solution: $50 \mu \mathrm{Mol}$ )

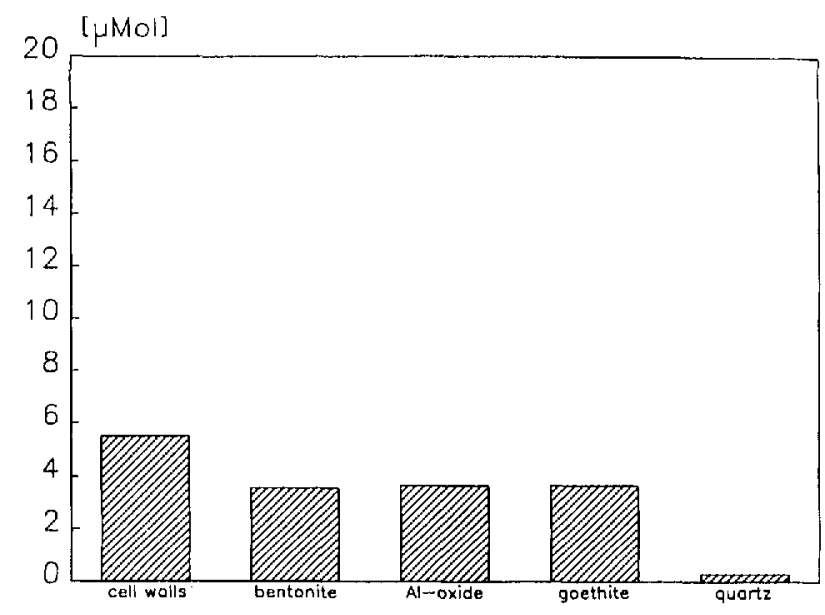

walls, and $\mathrm{Cu}$ and $\mathrm{Zn}$ the greatest affinity for goethite, Al oxide, and cell walls.

After addition of the seawater, Cd was clearly remobilized from all sediment components (Figs. $5 \mathrm{~A}-\mathrm{C}$ ). Displacement of sorbed $\mathrm{Cd}$ ions by alkali and alkali earth ions and formation of dissolved Cd-chloro complexes may be the main reasons for the observed mobilization. These effects have been found in natural estuarine systems (Mart and others 1985, Ahlf 1983, Calmano and others 1985) and indicate that Cd is relatively weakly bound to these solid materials.

A similar behavior was shown by $\mathrm{Zn}$ (Fig. 5B), with the exception that this metal was not displaced from bentonite by the seawater. Copper was also very strongly bound to bentonite (Fig. $5 \mathrm{C}$ ) with no remobilization occurring on mixing with seawater. Equally,
B Cu uptake by different solids
(amount in solution: $50 \mu \mathrm{Mol}$ )

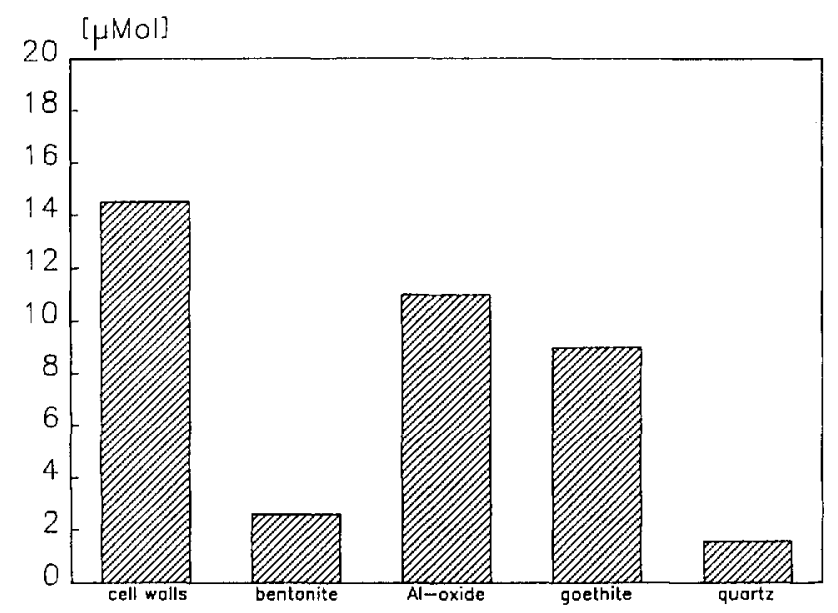

Figure 3. Sorption of (A) Cd, (B) Cu, and (C) Ni on model sediment components.

there was no remobilization of $\mathrm{Cu}$ bound to algal cells. The strong binding of $\mathrm{Cu}$ to organic matter has been reported by many authors. Even when the $\mathrm{pH}$ in the system was decreased to about 2.5 , only 30 percent of the algal-bound $\mathrm{Cu}$ was mobilized; nearly all the $\mathrm{Cd}$ and $\mathrm{Zn}$ was mobilized at this low $\mathrm{pH}$.

\section{Dredged Material/Seawater}

The intensity with which heavy metals are bound to natural aquatic sediments is important in the question relating to the dredging and disposal of contaminated sediments. In planning near-coast, subsediment disposal sites, information is needed on the behavior of metals during dredging, consolidation (changing redox and $\mathrm{pH}$ conditions), and disposal of dredged mud (ionic strength). 
$\mathrm{pH}$ values

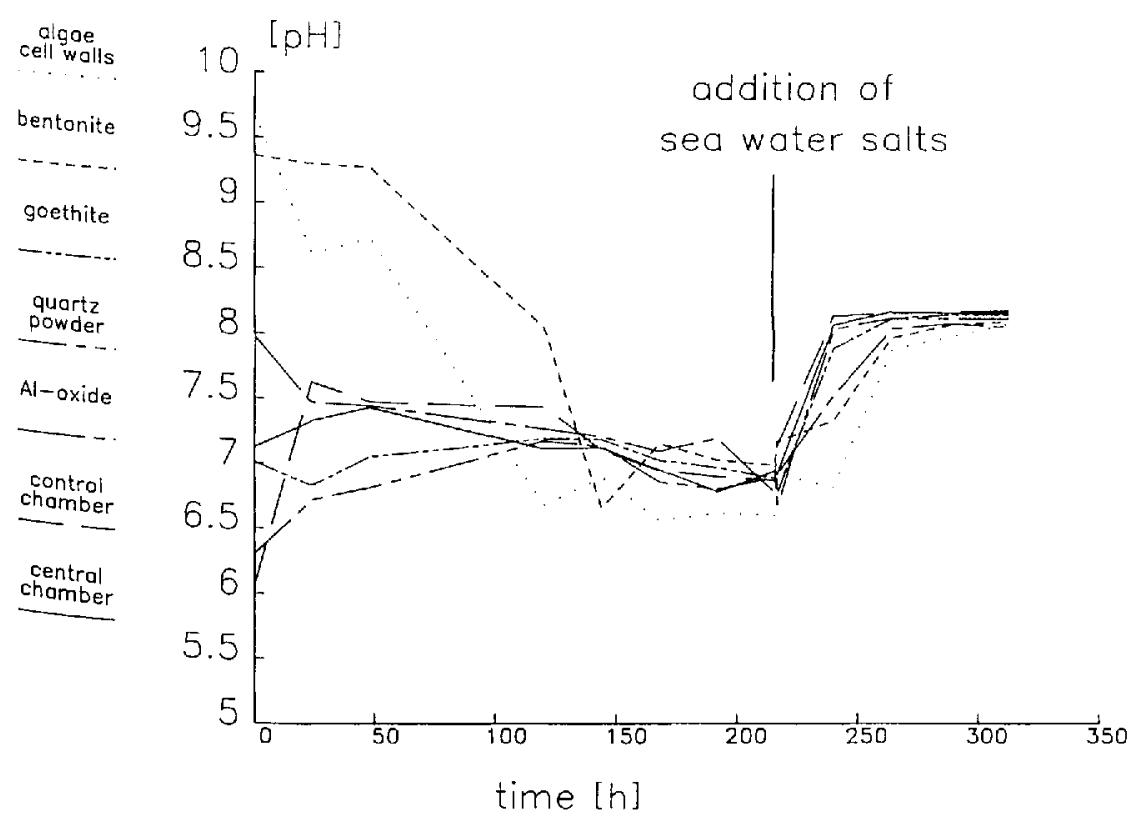

Figure 4. $\mathrm{pH}$ development in the different chambers as a function of time. Seawater addition after $10 \mathrm{~d}$.
We simulated the disposal of anoxic dredged mud from Hamburg harbor into seawater in an additional experiment. Again the multichamber device was operated with algal cell walls, bentonite, goerhite, quartz power, and with $\mathrm{Mn}$ oxide instead of $\mathrm{Al}$ oxide. The solid concentrations were the same as the previous experiment $(\mathrm{Mn}$ oxide $=200 \mathrm{mg})$. The device was filled with artificial seawater, and the dredged mud was added to the central chamber.

The $\mathrm{pH}$ development was found to be strongly dependent on the sludge content. Figure 6 shows the $\mathrm{pH}$ values in the single chambers for a sludge dry weight of 2 percent. For higher sludge contents (e.g., 10 percent) $\mathrm{pH}$ in the central chamber dropped to 4.5 , which of course influenced sorption/desorption behavior of the heavy metals. The oxidation of sulfides present in this sludge, together with its low buffer capacity, caused the $\mathrm{pH}$ variations.

The mobilization of $\mathrm{Cd}, \mathrm{Zn}$, and Cu from dredged mud by seawater after 3 weeks and the simultaneous readsorption on the model sediment components is shown in Figure 7 . The circles on the right represent the total metal content in the sludge, while those on the left show the percentage of each metal left in solution at the end of the experiment. The bars represent the total amount of metal transferred and sorbed on the single model sediment component. About 16 percent and 9 percent, respectively, of total $\mathrm{Cd}$ and $\mathrm{Zn}$ in the dredged mud are remobilized and found in solu- tion: less than $\mathrm{I}$ percent of the $\mathrm{Cu}$ was mobilized. Again, algal cell walls were the most important sorption sites for $\mathrm{Cd}$ and $\mathrm{Cu}$ in this model system, though sorption also occurred on the other components. Zn was mainly sorbed on bentonite, which agrees with the results of the previous experiments where $\mathrm{Zn}$ was found to strongly sorb to this clay mineral in seawater (see Fig. 5B). Readsorption may occur for metal species whose binding strength to model components exceeds their binding strength to dredged material, but this occurs only if metals are released from the sediments. This may lead to metal enrichment (e.g., $\mathrm{Cu}$ in biota), although the enrichment is not reflected by an increased solution concentration.

\section{Conclusions}

The multichamber device allows the investigation of heavy metal sorption/desorption processes on typical sediment components, with more or less stable binding sites, which are in competition for the metal. The surface effects vary from element to element (and particle type), and are significantly influenced by salinity. It is possible to study the influence of single components on the metal transfer from aqueous phase to solid phase, changing type and concentration of the solids. Simultaneously changing environmental conditions (e.g., $\mathrm{pH}$, redox potential, ionic strength) and the influence of complexing substances can be simulated 
A

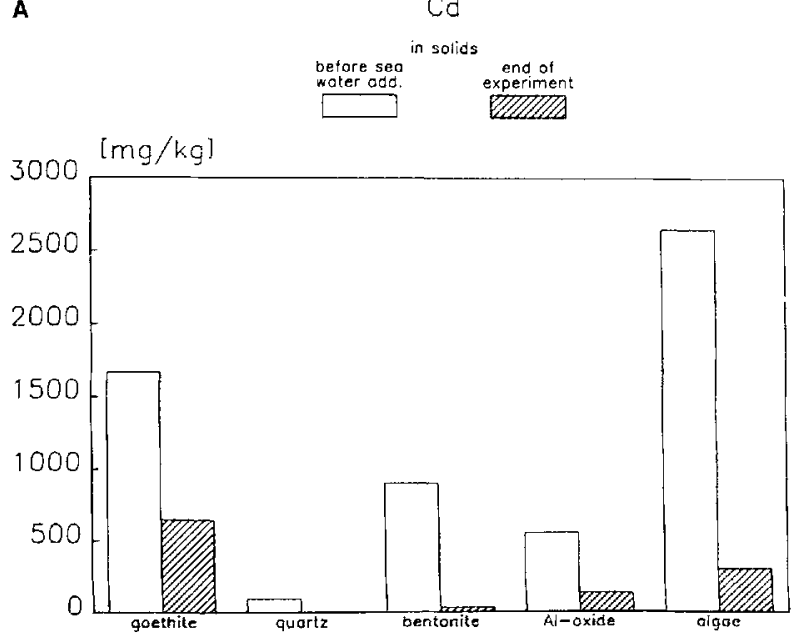

C
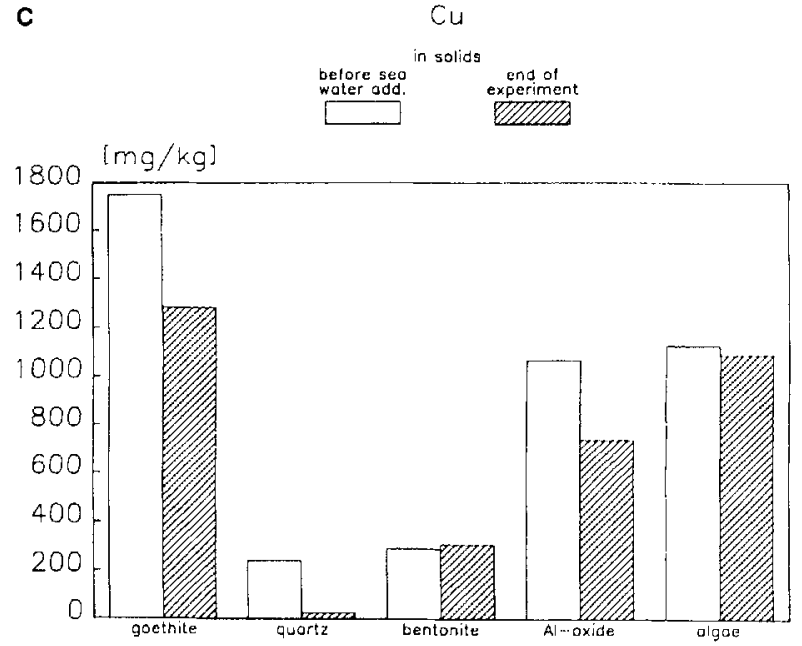

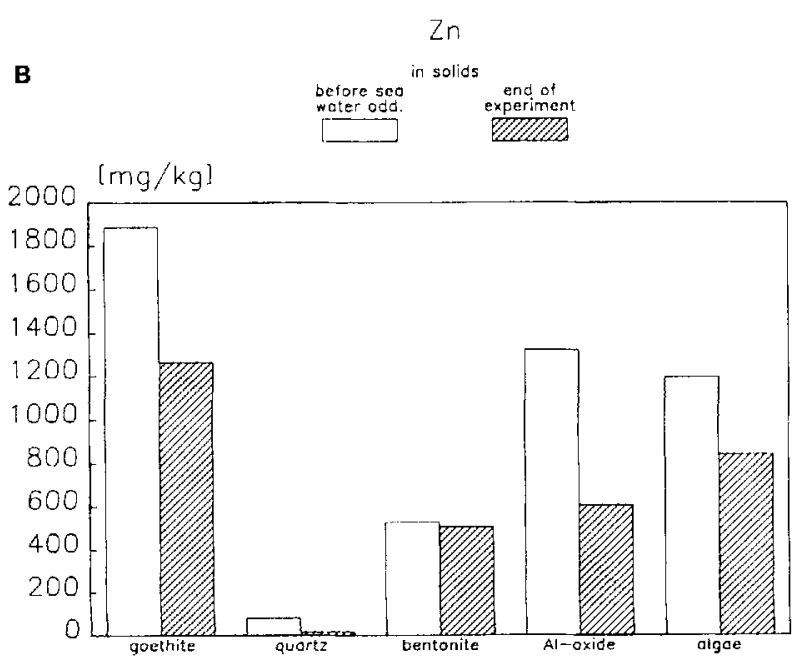

Figure 5. Sorption and desorption of (A) Cd, and (B) Zn, and $(\mathbf{C})$ Cu before and after addition of seawater.

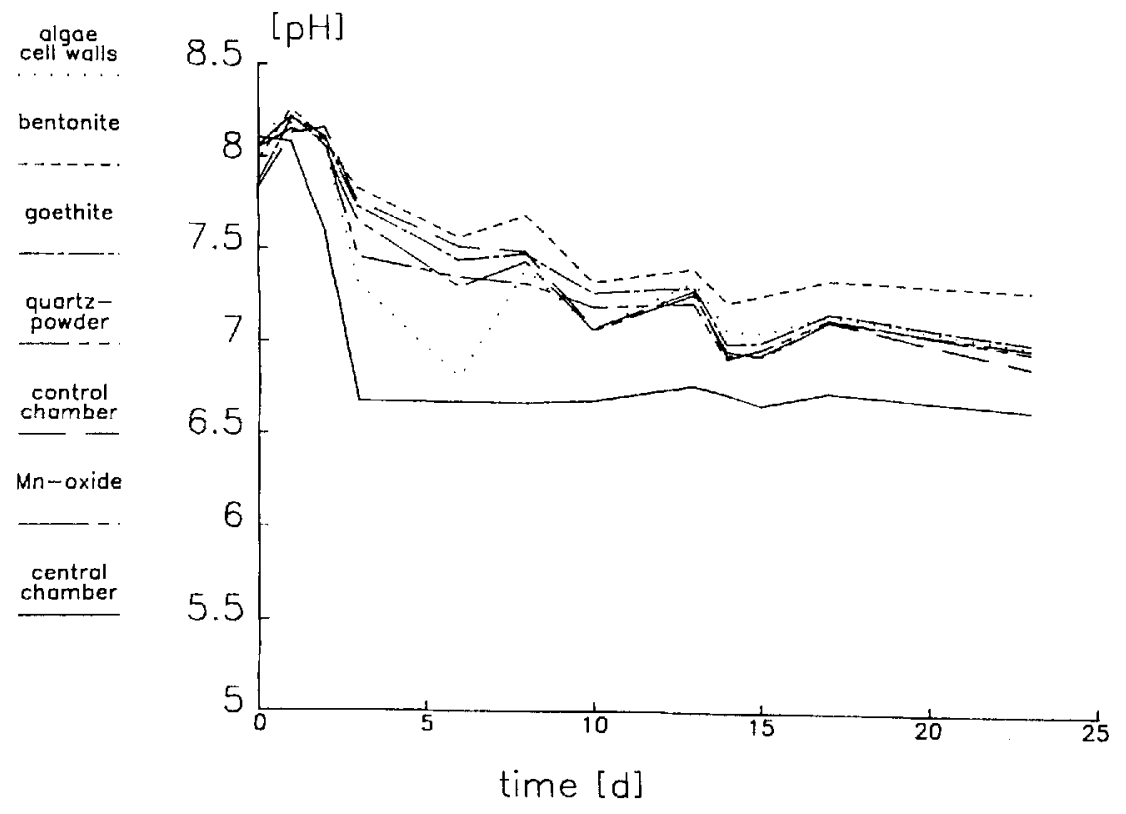

Figure 6. $\mathrm{pH}$ development in a dredged mud/seawater system (sludge content: 2 percent). 

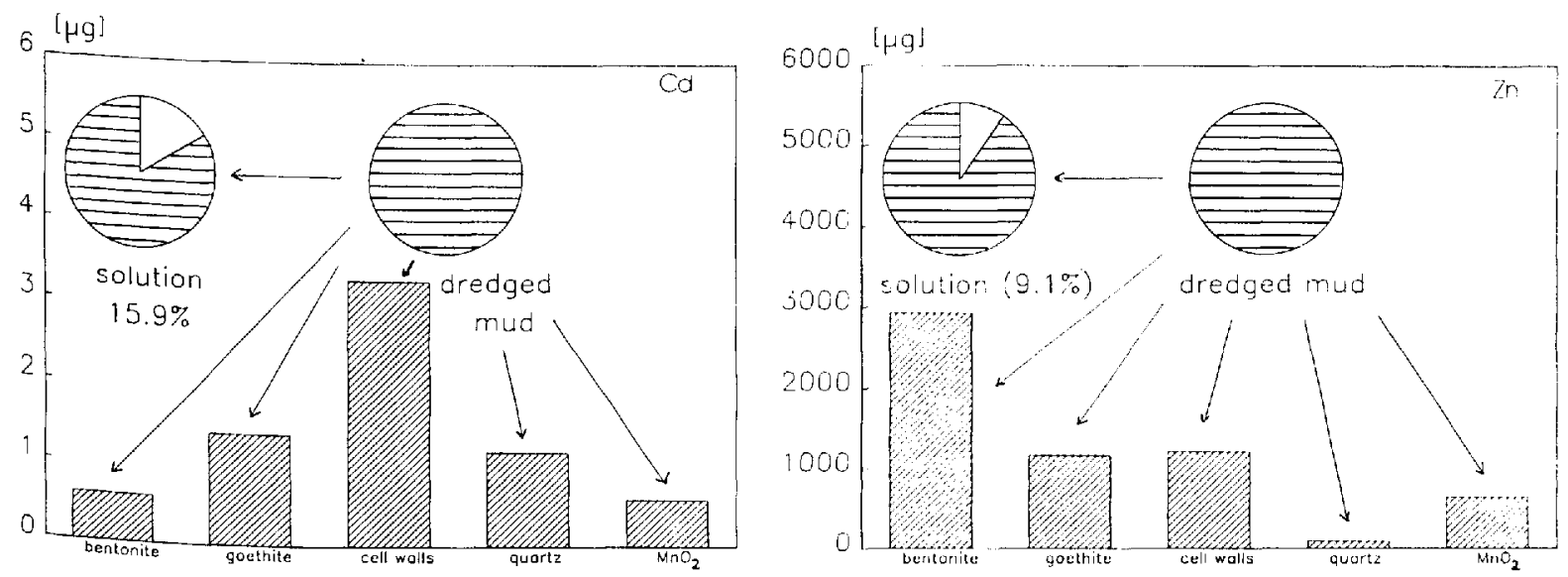

C

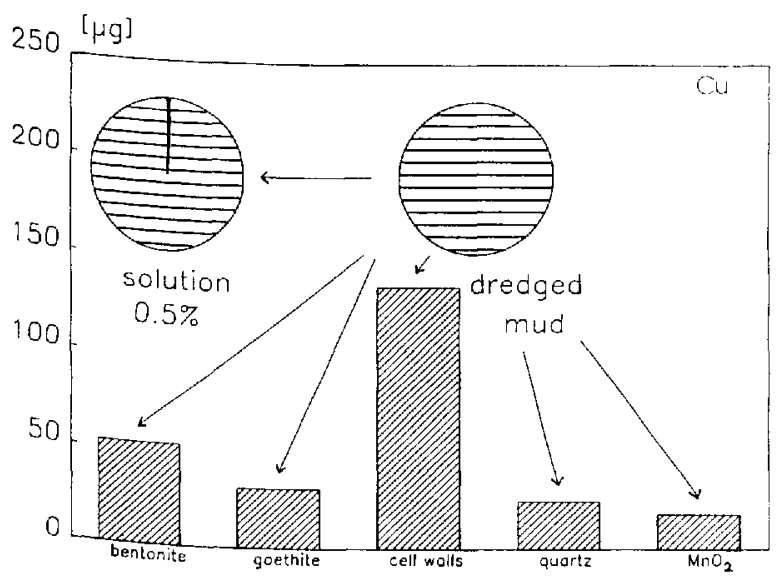

Figure 7. Mobilization of (A) Cd, (B) Zn, and (C) Cu from dredged mud and readsorption on different model sediment components in artificial seawater.

and the kinetics of the metal transfer may be investigated.

The dominant role of organic substrates in the binding of metals such as $\mathrm{Cd}$ and $\mathrm{Cu}$ is of particular relevance for the transfer of these elements into biological systems. Even at relatively small percentages of organic substrates these materials may be involved in metabolic processes and thus may constitute the major carriers by which metals are transferred within the food chain. Here, however, quantitative information is lacking on the mechanisms and effects involving degradation products and on the significance of biological processes in these laboratory systems.

The investigations reported here related to the effect of $\mathrm{pH}$ and redox changes and the influence of organic chelators on the distribution of metals between the individual substrates. Another series of experiments using radionuclides will investigate the remobilization of previously adsorbed metals on competing

substrates. The information produced will be useful for predicting intensities and reversibilities of metal associations under different environmental conditions and for establishing technologies against excessive mobility, for example, by application of chemical additives in critical systems.

\section{Acknowledgment}

We thank Mrs. Irene Brauer, who carried out the experimental and analytical work.

\section{References Cited}

Ahlf W., 1983, The river Elbe: behaviour of $\mathrm{Cd}$ and $\mathrm{Zn}$ during estuarine mixing; Environ. Technol. Lett., v. 4, p. $405-410$.

Ahlf, W., 1985, Verhalten sedimentgebundener Schwermetalle in einem Algentestsystem, charakterisiert durch 
Bioakkumulation und Toxizitat: Vom Wasser, v. 65, p. 183-188.

Ahlf, W., W. Calmano, and U. Förstner, 1986, 'The effects of sediment-bound heavy metals on algae and importance of salinity, in P. G. Sly, ed., Sediments and Water Interactions: New York, Springer-Verlag, p. 319-324.

Alkinson, R., A. Posner, and J. Quirk, 1967, Adsorption of potential determining ions at the ferric oxide aqueous electrolyte surface: J. Phys. Chem., v. 71, p. 550-558.

Battelle Labs., 1985, Sediment Quality Criteria Development Workshop, Nov. 28-30, Battelle, Washington, D.C., p. 25.

Benjamin, M. M., and J. O. Leckie, 1981, Multiple site adsorption of $\mathrm{Cd}, \mathrm{Cu}, \mathrm{Zn}$, and $\mathrm{Pb}$ on amorphous iron oxyhydroxide: J. Colloid Interfac. Sci., v. 79, p. 209-221.

Calmano, W., S. Wellershaus, and H. Liebsch, 1985, The Weser estuary: a study on heavy metal behaviour under hydrographic and water quality conditions: Veroff. Inst. Meeresforsch. Bremerh., v. 20, p. 15l-182.

Davies-Colley, R. J., P. O. Nelson, and K. J. Willianson, 1984, Copper and cadmium uptake by estuarine sedimentary phases: Environ. Sci. 'Technol., v. 18, p. 491-499.

DePinto, J. V., 1982, An experimental apparatus for evaluating kinetics of available phosphorus release from aquatic particulates; Water Res., v. 16, p. 1065-1070.

Forstner, U., 1985, Chemical forms and reactivities of metals in sediments, in R. Leschber, R. D. Davis, and P. O. L'Hermite, eds., Chemical Methods for Assessing Bioavailable
Metals in Sludges and Soils: London, Elsevier Applied Science Publ., p. 1-31.

Gamble, D. S., A. W. Underwood, and C. H. Langford, 1980, Copper (II) titration of fulvic acid ligand sites with theoretical potentiometric and spectrophotometric analysis: Anal. Chem., v. 52, p. 1901-1908.

Honeyman, B. D., 1984, Metal and metalloid adsorption at the oxide/water interface in systems containing mixtures of adsorbents: Ph.D. thesis, Stanford University, Stanford, California.

Jenne, E. A., D. M. Di'Toro, H. E. Allen, and C. S. Zarba, 1986, An activity-based model for developing sediment criteria for metals, in J. N. Lester, R. Perry, and R. M. Sherritt, eds., Chemicals in the Environment: London, Selper Ltd., p. 560-568.

Leckie, J. O., 1986, Adsorption and transformation of trace element species at sediment/water interfaces, in $\mathrm{M}$. Bernard, F. E. Brinckman, and P. J. Sadler, eds., The Importance of Chemical Speciation in Environmental Processes, Dahlem Workshop Report, v. 33, p. 237-254: Berlin, Springer Verlag.

Luoma, S. N., and J. A. Davies, 1983, Requirements for modelling trace metal partioning in oxidized estuarine sediments: Mar. Chem., v. 12, p. 159-181.

Mart, L., H. W. Nurnberg, and H. Rutzel, 1985, Levels of heavy metals in the tidal Filbe and its estuary and the heavy metal input into the sea: Sci. 'Total Environ., v. 44, p. $35-49$. 